\title{
KEDUDUKAN PERKAWINAN BEDA AGAMA DAN PERKAWINAN CAMPURAN DI INDONESIA
}

\author{
Mariani \\ Fakultas Syariah UIN Antasari Banjarmasin \\ mariani@uin-antasari.ac.id
}

Diterima 06-03-2020 | Direview 02-04-2020 | Diterbitkan 27-06-2020

\begin{abstract}
There are two categories of mixed marriages in Indonesia, namely mixed marriages between religions / different religions and mixed marriages across countries / different nationalities. This research method using descriptiveanalytical method. The conclusions are: Mixed marriages carried out in Indonesia refer to the applicable marriage laws in Indonesia. In order to carry out mixed marriages between Indonesian citizens and citizens of other countries, in general the requirements for marriage as regulated in the marriage law must first be met; Mixed marriages across countries, namely marriages made by Indonesian citizens with foreign citizens are allowed and legalized / recognized by the State, as long as all the terms and conditions regulated by the laws of the respective countries of origin of the bride and groom are fulfilled and there is no probibition for both of them to carry out wedding; and Islamic Law and Indonesian Positive Law allow marriage between two people of different nationalities, but probibit mixed marriages due to religious differences and do not obtain legal legality.
\end{abstract}

Keywords: Position, Marriage, Religious Differences, Mixture, Indonesia

\begin{abstract}
Abstrak
Ada dua kategori praktek perkawinan campuran di Indonesia yaitu perkawinan campuran lintas agamal beda agama dan perkawinan campuran lintas negaral perbedaan kewarganegaraan. Metode penelitian ini menggunakan metode deskriptif-analitis. Adapun simpulannya yaitu: Perkawinan campuran yang dilaksanakan di Indonesia mengacu pada bukum perkawinan yang berlaku di Indonesia. Untuk melaksanakan perkawinan campuran antara warga negara Indonesia dengan warga negara lain, secara umum harus dipenubi terlebih dahulu persyaratan-persyaratan perkawinan sebagaimana diatur dalam undang-undang perkawinan; Perkawinan campuran lintas Negara yaitu perkawinan yang dilakukan oleh Warga Negara Indonesia dengan Warga Negara Asing dibolebkan dan mendapat legalitas / pengakuan Negara, selama segala syarat dan ketentuan yang diatur oleh bukum masing-masing negara asal kedua mempelai tersebut terpenubi serta tidak ada larangan bagi keduanya
\end{abstract}


untuk melangsungkan pernikahan; serta Hukum Islam dan Hukum Positif Indonesia membolehkan perkawinan antara dua orang yang berlainan kewarganegaraan, namun mengharamkan perkawinan campuran karena perbedaan agama dan tidak mendapatkan legalitas hokum.

Kata kunci: Kedudukan, Perkawinan, Beda Agama, Campuran, Indonesia

\section{Pendahuluan}

Kehadiran Undang Undang Perkawinan No 1 Tahun 1974 tentang Perkawinan dalam bentuk hukum positif sebagaimana telah diubah dengan Undang Undang Nomor 16 Tahun 2019 Tentang Perkawinan beserta peraturan pelaksanaannya, kemudian Kompilasi Hukum Islam ( Instruksi Presiden No 1 Tahun 1991 ) di mana peraturan di dalamnya dianggap oleh sebagian pakar hukum merupakan hukum positif dan hukum materiil yang mengatur tentang perkawinan bagi masyarakat muslim di Indonesia. Kehadiran UUP No 1 Tahun 1974 dan perubahan nya serta terbitnya peraturan yang ada di Kompilasi Hukum Islam merupakan sebuah inovasi dan prestasi dari para pakar hukum dalam mencari suatu solusi dari berbagai masalah yang dihadapi bangsa Indonesia pada saat itu, dan sekarang, terbitnya Undang Undang perkawinan ini tentu saja diberbagai hal terjadi perubahan yang sangat signifikan serta mendasar dalam system hukum perkawinan nasional kita. Sebagaimana kita ketahui bahwa sebelum hadirnya UUP ini pemberlakuan keputusan beraneka ragam disesuaikan dengan golongan penduduk masing masing . dengan hadirnya UUP berubah menjadi unifikasi dan berlaku secara nasional bagi seluruh golongan penduduk yang ada. Ada hal yang mendasar pada UndangUndang Perkawinan tersebut dimana sebelumnya system yang diberlakukan adalah sistem sekuler kemudian dirubah dengan sistem perkawinan dilaksanakan menurut hukum masing masing agamanya dan kepercayaannya ,walaupun demikian, dalam hal tertentu masih banyak pula menyisakan variasi variasi dengan memperhatikan perbedaan yang tidak mungkin dihindari akibat hukum agamanya yang berbeda . dan berbagai aneka ragam keyakinan yang dianut dan aliran kepercayaan yang cukup banyak. Dengan diberlakukannya Undang Undang Perkawinan No 1 Tahun 1974 dengan perubahan UU No 16 Tahun 2019 dan Kompilasi Hukum Islam ada beberapa hal yang mesti menjadi perhatian

1. Hal yang mungkin tidak bisa terhindari adalah terjadinya perkawinan lintas agama, bisa dikatakan sebagai perkawinan campuran dimana terlibatnya sepasang suami isteri yang berbeda agama tapi memiliki kewarganegaraan yang sama, atau sepasang suami isteri yang melakukan perkawinan 
campuran yang berbeda kewarganegaraannya hal, tentu ini bukan perkara yang mudah untuk diselesaikan karena masing masing agama ada perbedaan perbedaan yang sangat mendasar, Dalam Agama Islam misalnya ada aturan yang sangat ketat untuk bisa menikah dengan orang yang berbeda agama, meskipun sebagian akademisi membolehkan adanya praktik perkawinan campuran antara laki laki muslim dan perempuan ahli kitab, ini mengambil pendapat ulama yang membolehkan seorang laki laki muslim menikahi wanita kitabiyah. Untuk agama lain ada yang cukup longgar dalam hal kawin dengan orang yang berbeda agamanya dengan pemeluk agama yang lain, Perbedaan warga negarapun juga akan menuai masalah kalau tidak ada regulasi yang mengaturnya.

2. Perkawinan beda agama, beda negara tentu berdampak masalah pada kehidupan masyarakat, karena terkait dengan keyakinan, tertib hukum, sosial kemasyarakatan dan aturan aturan, adat/ kebiasaan lain yang tentu akan dirasakan oleh pihak pihak yang melakukannya.

3. Terjadi kontraversi dikalangan masyarakat, ada yang setuju adanya pernikahan lintas agama karena menyangkut hak asasi manusia yang seyogyanya harus dihargai secara proporsional disamping itu perkawinan lintas agama, lintas negara dianggab wajar mengingat pluralitas agama yang ada di Indonesia, perkawinan bersifat individual dan diluar wilayah agama masing masing juga termasuk juga perkawinan lintas Negara hal yang sangat memungkinkan mengingat era globalisasi yang segalanya serba canggih.dan banyaknya warga asing yang bekerja di Indonesia begitu juga banyak pekerja Indonesia yang bekerja di luar negeri.. Adapun mereka yang tidak sependapat berargumen bahwa perkawinan beda agama itu dianggab telah melakukan pelanggaran terhadap hukum agama masing masing dan tentu akan berpengaruh terhadap keharmonisan dan ketentraman dalam hidup berumah tangga

Untuk perkembangan hukum positif di Indonesia, keadaan ini tentu sangat menarik untuk dikaji dan dicarikan solusinya karena pada dasarnya kehadiran hukum adalah untuk mengatur, menata dan melindungi hak hak warga Negara serta mengakomodir segala yang terkait dengan kepentingan nya baik kepentingan pribadi maupun kepentingan social kemasyarakatan.

Di Indonesia, perkawinan di atur melalui Undang Undang No 1 Tahun 1974 tentang perkawinan (ditulis UU Perkawinan ) dalam pasal 2 ayat (1) UU Perkawinan dinyatakan bahwa "Perkawinan adalah sah, apabila dilakukan menurut masing masing agama dan kepercayaannya itu", Hal ini 
berarti bahwa jika hukum agama menyatakan suatu perkawinan sah, maka sah pula menurut hukum negara, kemudian pasal 2 ayat (2) dinyatakan bahwa" Tiap tiap perkawinan dicatat menurut peraturan perundang undangan yang berlaku" dalam prakteknya, Perkawinan orang orang Islam dicatatkan pada Kantor Urusan Agama ( KUA ) dan perkawinan orang orang non Islam dicatatkan pada kantor catatan Sipil ( KCS)

Melihat dari aturan ini pernikahan beda agama tidak diakomodir untuk dilakukan, karena tidak ada satupun pasal yang mengatur pernikahan beda agama, dan ini menimbulkan banyak tafsiran, pendapat yang mayoritas dianut oleh para ahli praktisi hukum adalah pelarangan perkawinan beda agama dengan alasan kajian sejarah pasal 2 ayat (1) UU No 1 tahun 1974 tentang perkawinan yang merupakan hasil kesepakatan antara Pemerintah, DPR dan masyarakat yang tidak menyetujui adanya pernikahan beda agama di Indoneseia. ${ }^{2}$

Adanya unsur "penyerahan ' secara operasional ini justru membuka ruang bagi adanya berbagai macam tafsir hukum baik terhadap klausul pasal tersebut maupun di dalam hukum agama atau kepercayaan pasangan yang akan menikah. Ada empat faktor yang membuat seseorang mentaati hukum, pertama compliance dimana seseorang patuh karena mengharap suatu imbalan dan menghindari sangsi ( reward and punishment) kedua, identification, kepatuhan hukum bukan karena nilai intrinsiknya namun agar kelompok tetap terjaga serta adanya hubungan baik dengan mereka yang diberi kewenangan untuk menerapkan peraturan, ketiga, Internalization yaitu kepatuhan yang secara intrinsic didasarkan pada harapan imbalan dimana isi atau nilai peraturan itu dipandang sesuai dengan nilai yang diyakini, terakhir, kepentingan para warga masyarakat terakomodir dan terjamin oleh hukum yang ada. Demikian pendapat dari Soerjono Soekanto dan Pospisil.

Keberanian seseorang dalam mengambil keputusan melakukan perkawinan beda agama atau perkawinan campuran adalah pandangan keagamaannya serta adanya factor lingkungan, seperti adanya organisasi yang memberikan fasilitas untuk bisa melakukannya, atau bisa juga karena ada fakar yang mendukung / melegetimasi, bisa juga karena factor dukungan dari keluarga, dan factor yang lebih dominan karena kekuatan cinta yang dimiliki

1 Undang-Undang Nomor 1 Tabun 1974 Tentang Perkawinan Sebagaimana Telab Diubah Dengan Undang-Undang Nomor 16 Tabun 2019 (Surabaya: Arkola, 2000).

2 Abu Bakar Alyasa, Perkawinan Muslim dengan Non-Muslim (Nangroe Aceh Darussalam: Dinas Syari'at Islam, 2008). 
pasangan yang bersangkutan. Di Indonesia muncul beberapa kelompok pemikiran keagamaan yang memberikan alternative terhadap pola piker mainstream keislaman yang ada, seperti Yayasan Wakaf Paramadina, Jaringan Islam liberal dikalangan Islam

Masyarakat adalah kumpulan dari anggota yang ada didalamnya yang mempunyai keterikatan satu sama lainnya dan juga terikat dengan aturan atau norma yang berlaku di masyarakat termasuk didalamnya norma hukum dan norma agama, norma social juga norma kesopanan dan norma kesusilaan Norma hukum dalam kajian sosiologi hukum tidak terlepas dari perkembangan masyarakat, hukum bersifat dinamis dan terus mengalami perubahan sesuai dengan perkembangan masyarakat itu sendiri rumusan aturan hukum berfungsi sebagai control social yang seyogyanya mampu memberikan jawaban atas persoalan yang terjadi di masyarakat..

Tuntutan akan perubahan social semestinya membawa dampak pada keberadaan system hukum yang selama ini berada dalam keajegan, kalau hukum statis ini akan menjadi problema yang besar karena tidak mampu menjadi solusi dari permasalahan yang ada, kendala yang terjadi dalam hal penegakan hukum dan penegakan keadilan. Kalau hukum dapat berjalan seirama dengan perkembangan masyarakat maka hajat dan keperluan masyarakat dapat di akomodir. Von Savigny mengatakan bahwa hukum akan tetap hidup dan berkembang seiring dengan perkembangan masyarakatatas dasar otoritasnya sendiri yang bermoral, dalam hal ini hukum harus tetap berfungsi atau berarti bagi kemaslahatan, keteraturan serta ketertiban masyarakat. ${ }^{3}$

Seperti yang sudah disampaikan di atas bahwa Undang Undang No 1 Tahun 1974 tentang perkawinan beserta peraturan pelaksanaannya telah mengatur segala persoalan perkawinan bagi masyarakat Indonesia, yang secara esensial tidak bisa dilepaskan dari tuntunan atau panduan keagamaan, khususnya dari segi hukum Agama Islam, hal tersebut dapat dicermati sejak awal perumusan pasal pada undang undang tersebut yang menyebutkan atau menjelaskan pengertian tentang perkawinan. Dalam pasal 1 Undang Undang No 1 Tahun 1974 tentang perkawinan menyebutkan, perkawinan adalah ikatan lahir batin antara seorang peria dengan seorang wanita sebagai suami isteri dengan tujuan membentuk keluarga rumah tangga yang bahagia dan kekal berdasarkan Ketuhanan Yang Maha Esa. ${ }^{4}$ Adapun dalam Kompilasi Hukum

\footnotetext{
${ }^{3}$ Ellya Rosana, "Hukum dan Perkembangan Masyarakat," Jurnal TAPLs 9 No.1 (June 2013).

4 Undang-Undang Nomor 1 Tahun 1974 Tentang Perkawinan Sebagaimana Telab Diubah Dengan Undang-Undang Nomor 16 Tabun 2019.
} 
Islam disebutkan bahwa Perkawinan menurut hukum Islam adalah Pernikahan, yaitu aqad yang sangat kuat atau Mitsaqun ghalizhan untuk mentaati perintah Allah dan melaksanakannya merupakan ibadah.

Adanya kata berdasarkan Ketuhanan Yang Maha Esa, ini suatu indikasi keterikatan yang sangat kuat antara perkawinan dan agama, ini bisa dilihat kelanjutan pasal berikutnya yaitu dalam pasal 2 ayat (1) yang menetukan bahwa perkawinan hanya sah apabila dilakukan menurut hukum masing masing agama dan kepercayaannya.

\section{Metode}

Metode penelitian ini menggunakan metode deskriptif-analitis, yang membahas kedudukan perkawinan beda agama dan perkawinan campuran di Indonesia dengan melakukan kajian Undang Undang Nomor 16 Tahun 2019 Tentang Perkawinan beserta peraturan pelaksanaannya, kemudian Kompilasi Hukum Islam ( Instruksi Presiden No 1 Tahun 1991).

\section{Perkawinan Campuran Karena Perbedaan Agama Menurut Hukum Islam dan Hukum Positif}

Menurut pandangan hukum Islam, tidak ada istilah pengertian campuran jika dimaknai sebagai perkawinan antara dua orang yang berlainan kewarganegaraan. Yang ada hukum dan ketentuannya adalah perkawinan campuran dalam pengertian karena perbedaan agama. Dalam Agama Islam, agama merupakan kriteria yang diutamakan saat seseorang memilih calon pasangan hidup, sebagaimana tergambar dalam sebuah hadis Rasulullah Saw. yang cukup populer, yaitu :

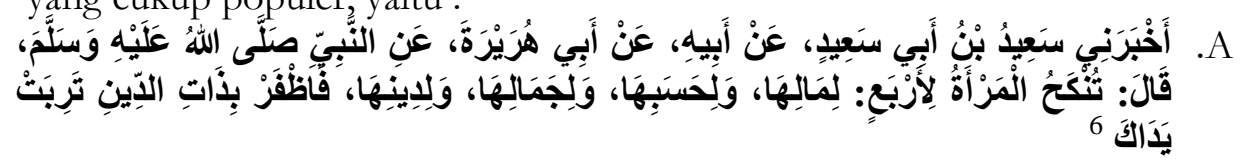

"Telah mengabarkan kepadaku Sa'id bin Abi Sa'id, dari ayahnya, dari Abu Hurairah, dari Nabi Saw. bersabda : Wanita itu (boleh) dinikahi karena empat hal : Karena hartanya, karena nasab keturunannya, karena kecantikannya, dan karena agamanya. Maka hendaklah kamu berpegang

\footnotetext{
${ }^{5}$ Departemen Agama Republik Indonesia, Kompilasi Hukum Islam (Instruksi Presiden Nomor 1, 1991).

${ }^{6}$ Abu al-Husain Muslim bin al-Hajjaj al-Qusyairi an-Naisaburi, Shabih Muslim, dalam Bab Tabrim al-Jam'u Baina al-Mar'ah, Juz II, Nomor Hadis 1408 (Maktabah Syamilah, 2014), hal. 1029.
} 
teguh (pada perempuan) yang memeluk agama Islam, (jika tidak) akan binasalah kedua tanganmu".

Dengan positivisasi hukum Islam ke dalam hukum perkawinan nasional, sebagaimana yang terumuskan dalam Pasal 2 ayat (1) undang-undang perkawinan yang mempunyai muatan makna bahwa perkawinan masyarakat Indonesia yang terjadi di Indonesia hanya dapat dilangsungkan ketika pasangan tersebut adalah pasangan yang se-agama walaupun berbeda ras, suku, ataupun bangsanya. Apalagi makna perkawinan campuran sebagaimana diatur dalam Pasal 57 sampai dengan Pasal 62 undang-undang Perkawinan telah menegaskan bahwa yang dimaksud dengan perkawinan campuran adalah perkawinan yang terjadi akibat karena adanya perbedaan kewarganegaraan. Dengan demikian, undang-undang perkawinan sendiri telah menegaskan ketidakabsahan perkawinan campuran karena perbedaan agama yang ingin melangsungkan pernikahannya di Indonesia.

Namun tidak dapat dipungkiri, dalam kehidupan masyarakat Indonesia yang plural, kriteria agama terkadang dikesampingkan dan tidak diutamakan. Sehingga tidak jarang ditemukan pasangan suami isteri yang berbeda keyakinan (agama). Padahal jika ditelusuri lebih jauh, perkawinan merupakan pemersatuan dua insan yang berbeda antara satu dengan yang lainnya untuk saling berkumpul, namun bukan dalam hal berbeda agama. Dalam definisi perkawinan sebagaimana ditegaskan dalam Pasal 1 Undang-Undang Nomor 1 Tahun 1974 telah menyebutkan bahwa tujuan sebuah perkawinan adalah untuk membentuk sebuah keluarga yang bahagia dan kekal berdasarkan Ketuhanan Yang Maha Esa.

Berdasarkan pengertian perkawinan tersebut, maka definisi perkawinan beda agama menjadi signifikan untuk dirumuskan dalam suatu peristilahan yang mudah dipahami. Dalam tulisannya, Karsayuda mendefinisikan perkawinan beda agama sebagai suatu ikatan perkawinan yang terjadi antara dua insan yang berbeda agama (keyakinan). Secara theologis, perkawinan beda agama tidak mendapatkan keabsahan dari agama manapun karena seluruh agama menolaknya, dengan hanya menghendaki perkawinan yang se-agama (satu keyakinan) saja. ${ }^{7}$ Dengan demikian, jelaslah bahwa perkawinan beda agama tidak mendapatkan tempat dalam ajaran agama manapun, tidak terkecuali agama Islam. Untuk lebih jelasnya bisa dilihat dalam Al-Qur'an ;

a) Surah al-Baqarah ayat 221:

\footnotetext{
7 M. Karsayuda, Perkawinan Beda Agama: Menakar Nilai-nilai Keadilan Kompilasi Hukum Islam (Yogyakarta: Total Media, 2006).
} 


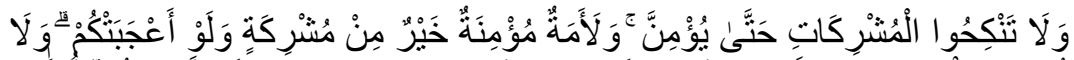

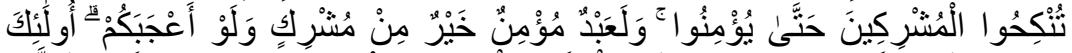

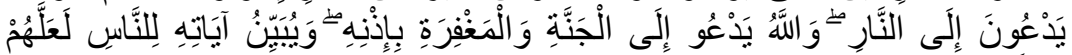

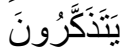

Artinya: "Dan janganlah kamu menikahi wanita-wanita musyrik, sebelum mereka beriman. Sesunggubnya wanita budak yang mukmin lebih baik dari wanita musyrik, walaupun dia menarik hatimu. Dan janganlah kamu menikabkan orang-orang musyrik (dengan wanita-wanita mukmin) sebelum mereka beriman. Sesunggubnya budak yang mukmin lebib baik dari orang musyrik, walaupun dia menarik hatimu. Mereka mengajak ke neraka, sedang Allah mengajak ke surga dan ampunan dengan izin-Nya. Dan Allah menerangkan ayat-ayat-Nya (perintab-perintab-Nya) kepada manusia supaya mereka mengambil pelajaran."

b) Surah al-Maidah ayat 5:

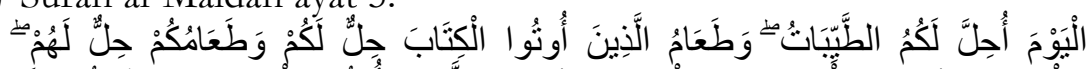

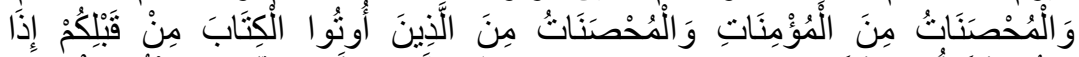

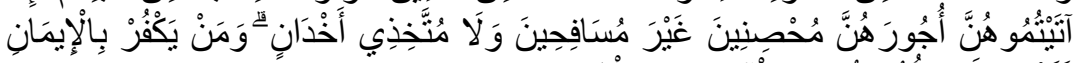

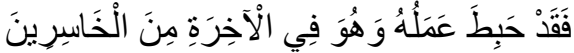

Artinya: "Pada hari ini dihalalkan bagimu yang baik-baik. Makanan (sembeliban) orang-orang yang diberi Al Kitab itu halal bagimu, dan makanan kamu balal (pula) bagi mereka. (Dan dibalalkan mengawini) wanita yang menjaga kehormatan diantara wanita-wanita yang beriman dan wanita-wanita yang menjaga kehormatan di antara orang-orang yang diberi Al Kitab sebelum kamu, bila kamu telah membayar mas kawin mereka dengan maksud menikahinya, tidak dengan maksud berzina dan tidak (pula) menjadikannya gundik-gundik. Barangsiapa yang kafir sesudah beriman (tidak menerima hukum-bukum Islam) maka hapuslah amalannya dan ia di hari kiamat termasuk orang-orang merugi."

Dari bunyi teksnya, dua ayat di atas memiliki konteks hukum yang berbeda. Ayat pertama pada surah al-Baqarah ayat 221 mengungkapkan larangan laki-laki dan wanita beriman kawin dengan orang-orang musyrik. Sedangkan ayat kedua pada surah al-Maidah ayat 5 memperbolehkan laki-laki Muslim mengawini wanita Ahli Kitab. Terkait asbabun nuqul surah al-Baqarah ayat 221 terdapat dua riwayat yang berbeda.

a. Riwayat Pertama

Diriwayatkan bahwa ayat ini turun berkenaan dengan "Martsad bin Abi Martsad al-Ghanawi yang membawa tawanan perang dari Mekkah 
menuju Madinah, dan semasa zaman jahiliyah ia memiliki hubungan dengan seorang wanita yang disebut 'Inaq, lalu wanita ini mendatanginya dan berkata: "Kenapa kita berpisah? Martsad menjawab: "Sesungguhnya Islam telah memisahkan kita berdua." Wanita ini berkata: "Maukah engkau mengawini diriku?", Martsad menjawab: "Ya, akan tetapi setelah aku kembali ke hadapan Rasulullah Saw dan aku akan memohon izin kepadanya." Maka turunlah ayat ini. Namun imam As-Suyuthi mengkritisi periwayatan ini dan menyebutkan bahwa riwayat tersebut bukanlah sebab yang melatarbelakangi turunnya ayat ini, akan tetapi merupakan sebab turunnya ayat di surah an-Nur yang berbunyi:

b. Riwayat Kedua

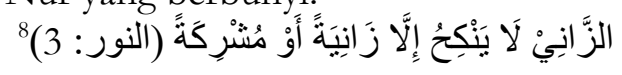

Al-Wahidi meriwayatkan dari jalur as-Suddi dari Malik dari Ibnu

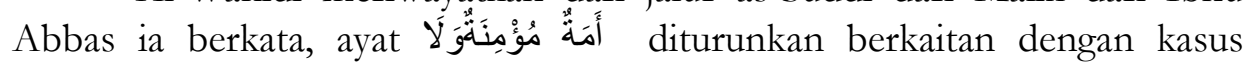
Abdullah bin Rawahah yang menyesal atas perlakuannya, lantas mendatangi Nabi Saw, ia menceritakan kepada Nabi Saw, dan berkata: "Sungguh saya akan memerdekakan dan mengawininya." Setelah itu ia melaksanakan tekadnya itu. Sebagai imbasnya, banyak orang mencerca Abdullah bin Rawahah karena mengawini budak, kemudian turunlah ayat tersebut. ${ }^{9}$ Dalam versi kitab lain menyebutkan bahwa Abdullah bin Rawahah memiliki seorang budak berkulit hitam, dan suatu hari ia pernah marah dan memukulnya, kemudian ia menyesal lalu mendatangi Nabi dan menceritakannya, Nabi berkata kepadanya: "Bagaimana sikapnya wahai Abdullah?", Abdullah menjawab: "Ia senantiasa berpuasa, sholat, membaguskan wudhu dan bersaksi bahwa tiada Tuhan selalin Allah dan bahwasanya engkau utusan-Nya. Lalu Nabi menanggapi: "Wahai Abdullah, ia adalah wanita yang beriman", Abdullah berkata: "Demi dzat yang mengutusmu dengan membawa kebenaran, sungguh aku akan memerdekakan dan mengawininya". Lalu ia melaksanakan sumpahnya tersebut, kemudian banyak orang Islam mencelanya saat itu. Dan mereka berkata: "Ia menikahi seorang budak". Dulunya mereka ini lebih senang

\footnotetext{
${ }^{8}$ Muhammad 'Ali al-Shobuni, Rawai' al-Bayan, (Beirut: Dar al-kutub al-'Ilmiyyah, 1999) Jilid I h. 201

${ }^{9}$ Muhammad Rasyid Ridha, Tafsir Al-Manar, Jilid III (Beirut: Dar al-Fikr,tt, n.d.).
} 
menikahi wanita musyrik karena kecenderungan terhadap kedudukan mereka. Lalu turunlah ayat ini. ${ }^{10}$

Kemudian pengertian musyrik itu sendiri yang berhasil penulis kumpulkan dari berbagai kitab tafsir sendiri ialah:

1) Setiap orang yang mengingkari Nabi Saw. Dan secara bahasa dipakaikan untuk semua orang kafir."

2) Ungkapan syirik jika digunakan dalam al-Qur'an maksudnya ialah: orang yang menyembah patung dan berhala dari kalangan Arab, dan termasuk pula yang sejenis dengan mereka seperti penganut agama budha dan lainnya, lebih-lebih lagi yang mengingkari adanya Allah. ${ }^{12}$

3) Abu Bakr al-Ashomm berkata: "Setiap orang yang mengingkari kerasulan dan mu'jizat maka orang tersebut adalah musyrik, karena mu'jizat itu berasal dari Allah ta'ala, sedangkan mereka menyandarkan mu'jizat tersebut kepada jin dan setan seraya berkata: "Sesungguhnya mu'jizat ini merupakan sihir", maka sungguh mereka telah menisbatkan adanya sekutu bagi Allah dalam menciptakan segala macam hal yang di luar dari kemampuan manusia. ${ }^{13}$

4) Musyrik dalam bahasa syari'at yaitu orang yang beragama dengan tuhan yang berbilang-bilang beserta Allah Swt. dan yang dimaksud dalam al-Qur'an adalah orang-orang musyrik dari kalangan Arab yang menyembah tuhan lain bersama Allah. ${ }^{14}$

Sedangkan surah al-Maidah ayat 5, mayoritas ulama menganggap sebagai nasakh atau pengecualian terhadap surah al-Baqarah pada ayat 221. Ahli kitab itu sendiri artinya ialah pemeluk agama Yahudi dan Nasrani. Ada yang mengatakan orang yang masuk ke dalam agama Yahudi dan Nasrani dari seluruh ummat sebelum diutusnya Nabi SAW. ${ }^{15}$

1. Fiqih

a) Pernikahan laki-laki muslim dengan perempuan musyrik

10 Abdurrahman bin Abi Bakr al-Suyuthi, Al-Durr al-Mantsur, (al-Maktabah al-Syamilab) Jilid II, Jilid II (Al-Maktabah al-Syamilah, n.d.).

${ }^{11}$ Ibrahim bin Al-Sariy, Ma'aniy al-Qur'an Wa I'robubu Lil Zajjaaj, Jilid I (Beirut: 'Alam al-Kutub, 1988).

12 Abdul Aziz At-Thorify, Al-Tafsir wal Bayan li Abkaam al-Qur'an, Jilid I (Riyadh: Maktabah Dar al-Minhaj, 2017).

${ }^{13}$ Umar bin Ali, Al-Lubaab Fi Uluum al-Kitab, Jilid IV (Beirut: Dar al-Kutub al-'Ilmiyyah, 1998).

${ }^{14}$ Muhammad At-Thohir, Tafsir Al-Tabriir Wal Tanwiir, Jilid II (Tunisia: al-Daar al-Tunisiyyah, 1984).

${ }^{15}$ Shiddiq Hasan Khan, Fath Al-Bayan Fi Maqashid al-Qur'an, Jilid II (Beirut: Dar al-Kutub al'Ilmiyyah, tt, n.d.). 
Seorang muslim tidak boleh kawin dengan seorang perempuan musyrik, yaitu perempuan yang menyembah Allah bersama tuhan yang lain, seperti berhala, atau bintang-bintang, atau api, atau binatang.

Yang juga memiliki kondisi ini adalah perempuan atheis atau materialis, yaitu orang yang mempercayai materi sebagai tuhan serta dia mengingkari keberadaan Allah. dia juga tidak mengakui berbagai agama samawi, seperti atheis, eksistensial, al-Baha'iyyah, dan al-Qadiyaniyyah. Berdasarkan firman Allah Swt, "Dan janganlah kamu menikabi wanita-wanita musyrik, sebelum mereka beriman. Sesungguhnya wanita budak yang mukmin lebih baik dari wanita musyrik, walaupun dia menarik batimu." (al-Baqarah: 221)

Madzhab Hanafi dan Syafi'i serta madzhab yang lainnya memasukkan perempuan yang murtad ke dalam golongan perempuan musyrik. Tidak ada seorang muslim atau kafir yang boleh mengawininya. Karena dia telah meninggalkan agama Islam. Dia tidak mengakui kemurtadannya. Dia memiliki pilihan antara mati atau masuk Islam. Murtad memiliki makna mati, karena dia adalah yang menjadi penyebab bagi kematian, dan orang yang mati tidak bisa dikawini.

Kesimpulannya, menurut kesepakatan fuqaha tidak boleh menikahi perempuan yang tidak termasuk ahli kitab, seperti watsaniyyah, yaitu perempuan yang menyembah berhala atau patung. Majusiyyah, yaitu perempuan yang menyembah api. Karena tidak ada kitab oleh para pemeluknya sekarang ini. kita tidak mempercayai dari sebelumnya, maka kita berhati-hati.

Penyebab bagi pengharaman mengawini perempuan musyrik dan yang sejenisnya adalah tidak adanya keharmonisan, ketenangan, dan kerjasama di antara suami-istri. Karena perbedaan akidah menumbuhkan rasa gelisah dan ketidaktenangan, dan perpecahan di antara suami-istri. Sehingga kehidupan rumh tangga yang seharusnya berdiri di atas landasan rasa sayang, kasih dan cinta tidak menjadi tenteram, dan tidak dapat tercapai tujuannya yang berupa ketenangan dan kestabilan. Kemudian, ketiadaan rasa keimanan terhadap suatu agama membuat seorang perempuan mudah untuk melakukan pengkhianatan rumah tangga, kerusakan, dan keburukan. Serta membuat hilang rasa amanah, kelurusan, dan kebaikan dari dalam dirinya, karena dia mempercayai takhayul dan imajinasi serta dia terpengaruh dengan hawa nafsu, dan tabiat diri yang tidak etis. Karena tidak ada agama yang 
mengekangnya, dan tidak ada yang mendorong dia untuk beriman kepada Allah, hari kiamat, hisab dan kepada kebangkitan. ${ }^{16}$

b) Pernikahan perempuan muslimah dengan laki-laki non muslim

Semua ulama sepakat bahwa perempuan muslimah tidak diperbolehkan (haram) kawin dengan laki-laki non muslim, baik ahli kitab maupun musyrik. Pengharaman tersebut selain didasarkan pada QS. AlBaqarah ayat 221 juga didasarkan pada QS. Al-Mumtahanah ayat 10 yaitu: Dan janganlah kamu menikabkan orang-orang musyrik (dengan wanita-wanita mukmin) sebelum mereka beriman." (al-Baqarah: 221)

Juga firman Allah Swt:

'W abai orang-orang yang beriman apabila perempuan-perempuan mu'min datang berbijrah kepada kalian, maka hendaknya kamu uji (keimanan) mereka. Allah sesungguhnya mengetabui keimanan mereka. Maka jika kamu telah mengetahui babwa mereka (benar-benar) beriman, maka janganlah kamu kembalikan mereka kepada (suami-suami mereka) orang-orang kafir. Mereka tiada halal bagi orang-orang kafir itu dan orang-orang kafir itu tiada halal pula bagi mereka." (al-Mumtahah: 10)

Sayyid Sabiq menyebutkan beberapa argumen sebab diharamkannya perempuan muslim kawin dengan laki-laki non-muslim sebagai berikut:

1) Orang kafir tidak boleh menguasai orang Islam berdasarkan QS. AnNisaa ayat 141 artinya, " Allah sekali-kali tidak akan memberi jalan kepada orang-orang kafir untuk. memusnabkan orang-orang yang beriman."

2) Laki-laki kafir dan Ahli Kitab tidak akan mau mengerti agama istrinya yang muslimah, malah sebaliknya mendustakan kitab dan mengingkari ajaran Nabi. Sedangkan Ahli Kitab dapat mengerti agama istrinya sebab ia mengimani kitab dari Nabi-Nabi terdahulu.

3) Dalam rumah tangga tidak mungkin suami istri hidup bersama dengan perbedaan keyakinan. ${ }^{17}$

c) Pernikahan laki-laki muslim dengan perempuan Ahli Kitab

Sementara pendapat fuqaha empat madzhab tentang laki-laki muslim mengawini perempuan Ahli Kitab adalah sebagai berikut:

1) Madzhab Hanafi

${ }^{16}$ Wahbah Az-Zuhaily, Wabbah Az-Zubailiy, al-Fiqh al-Islamiy Wa Adillatuh, Jakarta: Gema Insani, 2011) Jilid IX, Jilid IX (Jakarta: Gema Insani, 2011).

${ }^{17}$ Sayyid Sabiq, Fiqh Al-Sunnah, Jilid II (Beirut: Dar al-Kitab al-Arabi, 1985). 
Para ulama madzhab Hanafi mengharamkan seorang laki-laki muslim mengawini perempuan Ahli Kitab yang berdomisili di wilayah yang sedang berperang dengan Islam (dar al-harb). Hal demikian dikarenakan mereka tidak tunduk pada hukum orang-orang Islam sehingga bisa membuka pintu fitnah. Seorang suami muslim yang kawin dengan perempuan Ahli Kitab dikhawatirkan akan patuh terhadap sikap istrinya yang berjuang memperbolehkan anaknya beragama dengan selain agamanya. Suami tersebut akan memperdaya dirinya sendiri serta tidak lagi menghiraukan pengasingan dari pemerintah negara (Islam) nya.

2) Madzhab Maliki

Pendapat madzhab Maliki terbagi menjadi dua. Pertama, mengawini perempuan Ahli Kitab, baik di dar al-harb maupun dzimmiyah hukumnya makruh mutlak. Hanya saja kemakruhan pada dar al-harb kualitasnya lebih berat. Kedua, tidak makruh mutlak, sebab zhahir QS. Al-Maidah ayat 5 membolehkan secara mutlak. Tetapi tetap saja makruh sebab kemakruhannya berkaitan dengan dar al-Islam (pemerintahan Islam).

3) Madzhab Syafi'i

Fuqaha madzhab Syafi'i memandang makruh mengawini perempuan Ahli Kitab yang berdomisili di dar al-Islam, dan sangat dimakruhkan bagi yang berada di dar al-harb, sebagaimana pendapat fuqaha Malikiyah. Fuqaha Syafi'iyyah memandang kemakruhan tersebut apabila (1) tidak terbesit calon mempelai laki-laki muslim untuk mengajak perempuan Ahli Kitab itu masuk Islam, (2) apabila tidak mengawini Ahli Kitab itu ia bisa terperosok pada perbuatan zina.

4) Madzhab Hanbali

Laki-laki muslim diperbolehkan dan bahkan sama sekali tidak dimakruhkan mengawini perempuan Ahli Kitab berdasarkan keumuman QS. Al-Maidah ayat 5. Namun, disyaratkan agar wanita tersebut adalah wanita merdeka. ${ }^{18}$

Namun untuk saat ini, banyak terjadi perubahan terhadap kitab suci mereka, sehingga hal ini berdampak pada hukum menikah dengan perempuan Ahli Kitab. Penulis mengutip dalam kitab fiqih bermadzhab

${ }_{18}$ Abdurrahman Al-Jaziri, Kitab Al-Fiqh 'Ala al-Madzabib al-Arba'Ah (Beirut: Dar al-Kutub al'Ilmiyyah, tt, n.d.). 
Syafi'i yaitu al-Muhadzzab karya Abu Ishaq Ibrahim as-Syairazi yang menyebutkan bahwa:

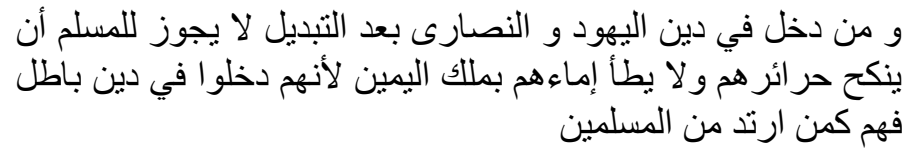

"Orang yang masuk dalam agama Yahudi dan Nasrani setelah terjadinya perubahan, maka lelaki muslim tidak boleh menikahi wanita-wanita merdeka dan bersetubuh dengan budak-budak mereka, karena mereka telah masuk dalam agama yang bathil, maka mereka itu hukumnya seperti orang muslim yang murtad"19

Sedangkan dalam kitab al-Hawiy al-Kabir menyatakan Ahli Kitab terbagi dua yaitu Bani Israil dan selain Bani Israil.

Pertama, Bani Israil yaitu mereka yang keturunan dari Nabi Ya'qub bin Ishaq bin Ibrahim As. Setiap keturunannya yang masuk ke dalam Agama Nabi Musa As masuk juga sebagiannya ke dalam agama Nabi Isa As (kala itu), mereka ada dalam agama yang benar sebelum terjadinya perubahan. Maka boleh menetapkan pajak terhadap mereka (sebagai jaminan keselamatanya), dan boleh memakan sembelihan dan menikahi wanita merdeka di kalangan mereka.

Kedua, selain Bani Israil yaitu terbagi tiga:

1) Sekelompok orang yang masuk agama Nasrani sebelum terjadinya perubahan kitab, seperti orang Rum ketika mereka memeluk agama Nasrani. Maka mereka itu hukumnya seperti orang-orang Bani Israel terhadap ditetapkannya mereka dalam pajak, dan diperbolehkan memakan sembelihan dan menikahi mereka. Karena Nabi Saw telah mengirimkan surat kepada Raja romawi waktu itu, Nabi menyampaikan dalam surat tersebut: "Katakanlah: Hai Abli Kitab, marilah (berpegang) kepada suatu kalimat (ketetapan) yang tidak ada perselisiban antara kami dan kamu, bahwa tidak kita sembah kecuali Allah.” (Ali 'Imron: 64). Maka Nabi memasukkan mereka ke dalam golongan Ahli Kitab, dan karena kehormatan itu sebab agama dan kitab bukan sebab nasab, oleh sebab itu tidaklah sama ketetapan hukum untuk Bani Israil dan selain dari mereka.

2) Sekelompok orang yang masuk agama Nasrani setelah terjadinya perubahan, mereka tidak berada pada kebenaran dan tidak

${ }^{19}$ Ibrahim bin Ali as-Syairazi, Al-Muhadzzab Fi Figh al-Imam al-Syafi'i, Jilid III (Beirut: Dar alKutub al-'Ilmiyyah, tt, n.d.). 
berpegang pada kitab yang akurat, maka mereka kedudukannya seperti penyembah berhala yang tidak diakui hak-hak mereka dengan penarikan pajak sebagai jaminan keselamatanya dan memakan sembelihan serta menikahi mereka tidak diperbolehkan.

3) Sekelompok orang yang diragukan apakah dia masuk agama Nasrani setelah terjadi perubahan atau sebelum terjadi perubahan, seperti orang-orang Nasrani bangsa Arab, Bani Wajj, Fihr, dan Taghlib. Maka mereka ini statusnya diragukan oleh sahabat Umar Ra, kemudian ia bermusyawarah dengan para sahabat, lalu mereka sepakat untuk mengakui hak-hak mereka dengan penarikan pajak sebagai jaminan keselamatanya, namun sembelihan dan menikahi wanita mereka tidak diperbolehkan. Karena darah itu dilindungi maka tidak diperbolehkan dengan adanya keragu-raguan, sedangkan kemaluan itu hukum asalnya adalah dilarang, maka tidak diperbolehkan karena ragu-ragu. ${ }^{20}$

2. Fatwa Ulama di Indonesia

a. Fatwa MUI

Dalam Musyawarah Nasional II pada 26 Mei-1 Juni 1980 (11 Rajab $1400 \mathrm{H}$ ), MUI menetapkan fatwa mengenai perkawinan campuran atau perkawinan beda agama. ${ }^{21}$ MUI dalam Munas II memfatwakan bahwa:

1) Hukum perkawinan perempuan dari kalangan muslimah dengan laki-laki yang bukan beragama Islam adalah haram.

2) Hukum perkawinan seorang laki-laki muslim dengan perempuan yang bukan dari kalangan muslimah (termasuk dengan perempuan dari kalangan ahli kitab) adalah haram. ${ }^{22}$

Setelah mempertimbangkan maslahat-mafsadat, MUI berkesimpulan bahwa mafsadat yang akan ditimbulkan dari perkawinan seorang laki-laki muslim dengan perempuan yang bukan dari kalangan muslimah (termasuk dengan perempuan dari

\footnotetext{
${ }^{20}$ Ali bin Muhammad al-Mawardi, Al-Hawi al-Kabir, Jilid IX (Beirut: Dar al-Kutub al-'Ilmiyyah, 1994).

${ }^{21}$ Jaih Mubarak, Pembaruan Hukum Perkawinan di Indonesia (Bandung: Simbiosa Rakatama Media, 2015).

${ }^{22}$ H.A Nazri Adlani, dkk., Himpunan Fatwa Majelis Ulama Indonesia (Jakarta: Majelis Ulama Indonesia, 1997).
} 
kalangan ahli kitab), lebih besar dibandingkan manfaatnya. Dengan demikian, MUI menetapkan keharaman perkawinan lakilaki muslim dengan perempuan non-muslim atas dasar pertimbangan maslabat. ${ }^{23}$

b. Fatwa Muhammadiyah

Pada 1990, diadakan Muktamar Tarjih Muhammadiyah di Universitas Muhammadiyah Malang (UMM). Setelah mempertimbangkan ayat-ayat al-Qur'an, Hadis Nabi, dan kaidah fikih, Majelis Tarjih Muhammadiyah menetapkan bahwa:

1) Laki-laki muslim diharamkan menikah dengan perempuan bukan muslimah

2) Perempuan muslimah diharamkan menikah dengan laki-laki yang bukan muslim. ${ }^{24}$

Majelis Tarjih Muhammadiyah mengharamkan perkawinan laki-laki muslim dengan perempuan bukan muslimah (termasuk ahli kitab) dan perkawinan seorang laki-laki yang masuk Islam (karena perkawinan semata) dengan perempuan muslimah atas dasar pertimbangan maslahat-mafsadat secara sosial, yaitu perkawinan sering kali dijadikan media oleh orang bukan muslim untuk melakukan pemurtadan. ${ }^{25}$

Dengan demikian, keputusan Muhammadiyah mengenai perkawinan antaragama (beda agama) dipengaruhi oleh dua pertimbangan:

1) Pertimbangan akademis, mereka mentapkan bahwa Yahudi dan Nasrani yang dijelaskan dalam al-Qur'an sudah tidak ada lagi setelah kerasulan Muhammad Saw

2) Pertimbangan sosiologis, yaitu pemurtadan terhadap muslimah yang dilakukan oleh orang-orang yang bukan Islam. ${ }^{26}$

c. Fatwa Nahdlatul Ulama

\footnotetext{
${ }^{23}$ Mubarak, Pembaruan Hukum Perkawinan di Indonesia.

24 PP Muhammadiyah, Tanfidz. Keputusan Muktamar Tarjïh Mubammadiyah XII, Malang (Yogyakarta: PP Muhammadiyah, 1990).

25 Laporan seksi I (Tuntunan Menuju Keluarga Sakinah) Muktamar Majelis Tarjih Muhammadiyah (11-16 Februari atau 6-10 Rajab 1409 H) di Malang, h. 4 atau h. 40

${ }^{26}$ Mubarak, Pembaruan Hukum Perkawinan di Indonesia.
} 
Berdasarkan Himpunan Keputusan Bahtsul Masa'il PWNU Jawa Timur, keputusan tersebut diperkirakan ditetapkan antara 1979-1986. Dengan demikian, keputusan BM-NU tentan Pernikahan beda agama juga merupakan respons terhadap UU Nomor 1 Tahun 1974 tentang Perkawinan, terutama pasal 2 ayat 1. Dari segi historis, BM-NU telah menetapkan hukum perkawinan beda agama sejak 1962 (jauh sebelum pembentukan UU Nomor 1 Tahun 1974 tentang Perkawinan), yaitu Muktamar NU 1962 dan keputusan tersebut kemudian dikuatkan lagi dalam Muktamar Thariqah Muktabarah $1968 .^{27}$

NU menetapkan perkawinan antara laki-laki muslim dengan perempuan bukan muslimah, dan perkawinan perempuan muslimah dengan laki-laki bukan muslim, adalah tidak sah. Alasan yang digunakan adalah pendapat ulama yang terdapat dalam enam kitab: (1) al-Syarqawi: Syarah dan Matannya; (2) alMubadzdzab fi Figh Madzhab al-Imam al-Syafi' karya al-Syirazi; (3) al-Umm karya Muhammad In Idris al-Syafi'i; (4) Abkam al-Fuqaha; (5) al-Majmu'Syarb al-Muhadzdzab karya al-Nawawi; dan (6) Tanwir al-Qulub. ${ }^{28}$

Menurut K.H. Ahmad Azhar Basyir, dalam buku beliau Kawin Campur, Adopsi da Wasiat Menurut Hukum Islam, diperbolehkannya laki-laki muslim mengawini perempuan abl al-kitab disebabkan adanya titik-titik persamaan antara ajaran-ajaran agama mereka dengan ajaran Islam. Hal itu disebabkan karena kedua agama itu berasal dari satu sumber, yaitu wahyu Allah yang mengajarkan iman kepada Allah, kepada akhirat, kepada kitab-kitab Allah, kepada malaikat dan kepada para rasul. Tetapi menurut beliau kebolehan itu tidaklah mutlak, karena masih ada kaitannya dengan jaminan keselamatan agama si suami sendiri dan anak-anaknya. Apabila dalam perkawinan itu suami yang muslim tersebut tidak mampu memegang pimpinan rumah tangga karena keadaan atau posisinya yang lemah, sehingga justru isteri yang abl al-kitab tersebut yang memegang kemdali pimpinan keluarga, sedang sang suami tunduk kepada isterinya dan bahkan anak-anaknya pun akan tersalur pendidikannya untuk mengikuti agama sang isteri, atau bahkan sang suami dikhawatirkan akan mengikuti agama isterinya dan meninggalkan agama

\footnotetext{
${ }^{27}$ Masyhuri Abdul Aziz, Masalah Keagamaan: Hasil Muktamar dan Munas Ulama Nabdhatul Ulama Surabaya (Surabaya: PP Rabithah Ma'ahidil Islamiyah dan Dinamika Press., 1977).

28 At-Thorify, Al-Tafsir wal Bayan li Abkaam al-Qur'an.
} 
Islamnya, maka kebolehan tersebut (menikahi perempuan abl al-kitab) tidak berlaku baginya. ${ }^{29}$

Lebih lanjut, dalam Kompilasi Hukum Islam pada Pasal 40 huruf (c) dengan tegas melarang perkawinan antara seorang pria dengan seorang wanita yang tidak beragama Islam. Sementara itu, Pasal 44 Kompilasi Hukum Islam juga memberikan penegasan tentang larangan perkawinan bagi seorang wanita muslim dengan seorang laki-laki non-muslim, yang bunyi pasalnya menyatakan : "bahwa seorang wanita Islam dilarang melangsungkan perkawinan dengan seorang pria yang tidak beragama Islam".

Perlu kita pahami bahwa ketentuan-ketentuan hukum Islam yang dirumuskan dalam Kompilasi Hukum Islam merupakan hasil kajian yang mendalam terhadap ayat-ayat nașsiyyah yang membicarakan tentang perkawinan, kewarisan dan perwakafan, yang kemudian oleh sebagian pakar hukum Islam menyebut Kompilasi Hukum Islam sebagai fikih dalam bahasa undang-undang, dikarenakan susunannya seperti layaknya undang-undang, yang berisi bab, pasal, dan ayat. Selain itu, isinya pun cukup terperinci dan mencakup persoalan-persoalan perkawinan, kewarisan dan perwakafan. ${ }^{30}$

Selain pendekatan normatif dengan mengemukakan ayat-ayat $\mathrm{Al}$ Qur'an dan kajian yuridis dengan berdasarkan pada undang-undang perkawinan beserta Kompilasi Hukum Islam, praktik perkawinan beda agama jika dikaji dengan pendekatan aspek sosial pun akan dapat menimbulkan halhal yang bertentangan dengan ajaran Islam. Dalam ilmu fikih terdapat satu kaidah yang cukup populer yang menyatakan bahwa mencegah kemudharatan

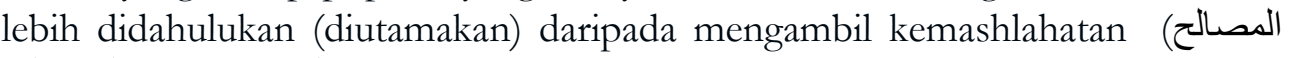
( ( درؤ الدفاسد مقدم علي جلب () Oleh karenanya, perkawinan beda agama akan melahirkan banyak akibat, baik bagi pasangan hubungan suami isteri tersebut, maupun bagi anak-anak yang dilahirkan dari perkawinan tersebut.

Di antara akibat-akibat yang timbul dari perkawinan beda agama adalah sebagai berikut:

a. Soal keabsahan perkawinan tersebut, yang akan menimbulkan hak dan kewajiban antara suami isteri (hak isteri terhadap nafkah dan harta bersama).

${ }^{29}$ H.Ainuddin Abdullah, Beberapa Materi Kultum: Upaya Meningkatkan Wawasan ke-Islaman, Gairah Beribadah dan Kualitas Ibadah (Banjarmasin: PT. Grafika Wangi, 2020).

30 A.Qodry Azizy, Eklektisisme Hukum Nasional Kompetisi antara Hukum Islam dan Hukum Umum (Yogyakarta: Gama Media, 2004). 
b. Status anak yang dilahirkan, anak yang lahir dari perkawinan yang tidak sah hanya mempunyai hubungan hukum dengan ibunya saja.

c. Hak kewarisan (karena perbedaan agama menggugurkan hak saling mewarisi).

d. Masalah pengadilan tempat menyelesaikan sengketa rumah tangga (Lembaga peradilan di Indonesia selain mengenal kewenangan absolut dan kewengan relatif, juga mengenal asas personalitas). ${ }^{31}$

Pernikahan beda agama di Indonesia ,tidak diatur dalam undangundang perkawinan nasional, karena perkawinan tersebut tidak dibenarkan oleh ajaran agama. Terdapat halangan perkawinan jika perkawinan tersebut tetap dilangsungkan, karena tidak sesuai dengan yang dikehendaki oleh Pasal 2 ayat (1) dan Pasal 8 huruf (f) undang-undang perkawinan. Pasal 2 ayat (1) menyatakan : Perkawinan adalah sah apabila dilakukan menurut hukum masing-masing agamanya dan kepercayaannya itu., hal tersebut dapat bermakna bahwa persyaratan pertama dan utama atas keabsahan sebuah perkawinan adalah mengacu pada hukum dan aturan agamanya masing-masing. Sedangkan menurut penjelasan Pasal 2 tersebut menyatakan bahwa tidak ada perkawinan di luar hukum masing-masing agamanya dan kepercayaannya itu, sesuai dengan Undang-Undang Dasar 1945.

B. Perkawinan Beda Agama dan Perkawinan Campuran Dalam Hukum Positif di Indonesia

1, Perkawinan Beda Agama

Di Indonesia, secara yuridis formal, perkawinan di Indonesia diatur dalam Undang-Undang Republik Indonesi Nomor 1 Tahun 1974 tentang Perkawinan dan Instruksi Presiden Republik Indonesia Nomor 1 Tahun 1991 tentang Kompilasi Hukum Islam. Kedua produk perundang-undangan ini mengatur masalah-masalah yang berkaitan dengan perkawinan termasuk perkawinan antar agama.

Dalam Undang-Undang Republik Indonesia Nomor 1 Tahun 1974 tentang Perkawinan pasal 2 ayat (1) disebutkan: "Perkawinan adalah sah, apabila dilakukan menurut hukum masingmasing agama dan kepercayaannya itu". Dalam rumusan ini diketahui bahwa tidak ada perkawinan di luar hukum masing-masing agama dan kepercayaan. Hal senada diterangkan beberapa pasal

\footnotetext{
${ }^{31}$ Karsayuda, Perkawinan Beda Agama: Menakar Nilai-nilai Keadilan Kompilasi Hukum Islam.
} 
dalam Instruksi Presiden Republik Indonesia Nomor 1 Tahun 1991 tentang Kompilasi Hukum Islam, sebagai berikut:

Pasal 4: "Perkawinan adalah sah, apabila dilakukan menurut hukum Islam sesuai dengan pasal 2 ayat (1) Undang-Undang No. 1 Tahun 1974 tentang Perkawinan". ${ }^{32}$

Pasal 40: Dilarang melangsungkan perkawinan antara seorang pria dengan seorang wanita karena keadaan tertentu;

a. Karena wanita yang bersangkutan masih terikat satu perkawinan dengan pria lain;

b. Seorang wanita yang masih berada dalam masa iddah dengan pria lain;

c. Seorang wanita yang tidak beragama Islam. ${ }^{33}$

Pasal 44: "Seorang wanita Islam dilarang melangsungkan perkawinan dengan seorang pria yang tidak beragama Islam". ${ }^{34}$

Pasal 61: "Tidak sekufu tidak dapat dijadikan alasan untuk mencegah perkawinan, kecuali tidak sekufu karena perbedaan agama atau ikbtilaf al-dien". ${ }^{35}$

Dengan demikian, menurut penjelasan pasal-pasal tersebut bahwa setiap perkawinan yang dilaksanakan dalam wilayah hukum Indonesia harus dilaksanakan dalam satu jalur agama, tidak boleh dilangsungkan perkawinan masing-masing agama, dan jika terjadi maka hal tersebut merupakan pelanggaran terhadap konstitusi.

\section{Perkawinan Campuran Karena Perbedaan Kewarganegaraan}

Tidak sedikit masyarakat memahami perkawinan campuran di Indonesia sebatas perkawinan beda agama saja. Padahal dalam prakteknya perkawinan campuran di Indonesia dapat diklasifikasikan dalam dua kategori, yaitu perkawinan campuran karena perbedaan agama dan perkawinan campuran karena perbedaan kewarganegaraan. Praktek perkawinan campuran saat ini telah berkembang maknanya dan tidak lagi mengacu pada pandangan klasik yang cenderung memahami perkawinan campuran sebagai perkawinan karena perbedaan agama.

Tidak dapat dipungkiri, perkawinan campuran karena perbedaan kewarganegaraan sudah banyak terjadi dan akan terus banyak terjadi di masa

\footnotetext{
${ }^{32}$ Republik Indonesia, Kompilasi Hukum Islam.

${ }^{33}$ Republik Indonesia.

${ }^{34}$ Republik Indonesia.

${ }^{35}$ Republik Indonesia.
} 
mendatang. Hal tersebut lumrah sebagai akibat pesatnya arus globalisasi dan informasi, ekonomi, pendidikan, dan transportasi. Jalur perkenalan masa kini telah membawa dan mempertemukan pasangan berbeda kewarganegaraan, dimana akses perkenalan dan saling komunikasi tersebut bisa dijalin melalui berbagai media seperti internet, berbagai macam aplikasi dan media-media sosial masa kini, hubungan bisnis dan dagang antar negara, teman pendidikan, bahkan liburan manca negara. Perkawinan campuran juga banyak terjadi pada tenaga kerja Indonesia yang bekerja di luar negeri dengan tenaga kerja dari negara lain. Oleh karena itu sudah semestinya perlindungan hukum atas praktik perkawinan campuran ini diakomodir dengan baik oleh negara dalam peraturan perundang-undangan di Indonesia.

Pada prinsipnya, perkawinan campuran yang dilaksanakan di Indonesia harus mengacu (berpedoman) berdasarkan hukum perkawinan yang berlaku di Indonesia. Untuk melaksanakan perkawinan campuran antara warga negara Indonesia dengan warga negara lain, secara umum harus dipenuhi terlebih dahulu persyaratan-persyaratan perkawinan sebagaimana diatur dalam undang-undang perkawinan. persyaratan-persyaratan tersebut tertuang dalam pasal 6 sampai dengan pasal 12 undang-undang perkawinan. Misalnya calon pengantin telah memenuhi syarat dalam hal batasan usia minimal perkawinan sebagaimana yang telah ditentukan oleh Undang-Undang Nomor 1 Tahun 1974 Tentang Perkawinan, yang mana dalam Pasal 7 ayat (1) (yang mengatur tentang ketentuan batasan usia minimal untuk menikah) sebagaimana telah diubah dengan Undang-Undang Nomor 16 Tahun 2019, menentukan minimal calon pengantin telah berusia 19 tahun (baik pihak pria maupun wanita). ${ }^{36} \mathrm{Jika}$ ketentuan pasal tersebut tidak terpenuhi maka menurut ketentuan ayat (2) orang tua pihak pria dan/atau orang tua pihak wanita dapat meminta dispensasi kepada pengadilan dengan alasan yang mendesak disertai bukti-bukti pendukung yang cukup.

Dalam Pasal 56 ayat (1) dan (2) Undang-Undang Nomor 1 Tahun 1974 Tentang Perkawinan, mengatur tentang perkawinan yang dilakukan di luar Indonesia, yaitu sebagai berikut :

(1) Perkawinan yang dilangsungkan di luar Indonesia antara dua orang warga negara Indonesia atau seorang warga negara Indonesia dengan warga negara asing adalah sah bilamana dilakukan menurut hukum yang berlaku di negara dimana perkawinan itu dilangsungkan dan bagi

\footnotetext{
36 Undang-Undang Nomor 1 Tabun 1974 Tentang Perkawinan Sebagaimana Telab Diubah Dengan Undang-Undang Nomor 16 Tabun 2019.
} 
warga negara Indonesia tidak melanggar ketentuan-ketentuan undangundang ini.

(2) Dalam waktu 1 (satu) tahun setelah suami isteri itu kembali di wilayah Indonesia, surat bukti perkawinan mereka harus didaftarkan di Kantor Pencatatan Perkawinan tempat tinggal mereka.

Dalam ayat (1) pasal tersebut secara jelas menyatakan bahwa keabsahan perkawinan yang dilakukan di luar wilayah Indonesia harus dilakukan menurut aturan perkawinan yang berlaku di negara dimana perkawinan tersebut dilangsungkan, dan bagi warga negara Indonesia perkawinan tersebut juga tidak boleh melanggar ketentuan dan aturan-aturan tentang perkawinan yang berlaku di Indonesia. Jika kedua suami isteri tersebut kembali ke Indonesia dan ingin menetap di negara Indonesia, maka dalam jangka waktu paling lama 1 (satu) tahun, perkawinan meraka harus didaftarkan (dicatatkan) di Kantor Pencatatan Perkawinan pada tempat dimana mereka berdomisili, dengan membawa surat-surat atau bukti-bukti perkawinan meraka, sehingga perkawinan mereka tersebut juga mendapatkan pengesahan (legalitas) dari negara.

Kemudian dalam Pasal 57 sampai dengan Pasal 62 Undang-Undang Nomor 1 Tahun 1974 Tentang Perkawinan, telah mengatur secara khusus tentang perkawinan campuran, yaitu sebagai berikut:

\section{Pasal 57}

Yang dimaksud dengan perkawinan campuran dalam Undang-undang ini ialah perkawinan antara dua orang yang di Indonesia tunduk pada hukum yang berlainan, karena perbedaan kewarganegaraan dan salah satu pihak berkewarganegaraan Indonesia.

\section{Pasal 58}

Bagi orang-orang yang berlainan kewarganegaraan yang melakukan perkawinan campuran, dapat memperoleh kewarganegaraan dari suami/isterinya dan dapat pula kehilangan kewarganegaraannya, menurut cara-cara yang telah ditentukan dalam Undang-undang kewarganegaraan Republik Indonesia yang berlaku.

\section{Pasal 59}

(1) Kewarganegaraan yang diperoleh sebagai akibat perkawinan atau putusnya perkawinan menentukan hukum yang berlaku, baik mengenai hukum publik maupun mengenai hukum perdata.

(2) Perkawinan campuran yang dilangsungkan di Indonesia dilakukan menurut Undang-undang Perkawinan ini. 


\section{Pasal 60}

(1) Perkawinan campuran tidak dapat dilangsungkan sebelum terbukti bahwa syarat-syarat perkawinan yang ditentukan oleh hukum yang berlaku bagi pihak masing-masing telah dipenuhi.

(2) Untuk membuktikan bahwa syarat-syarat tersebut dalam ayat (1) telah dipenuhi dan karena itu tidak ada rintangan untuk melangsungkan perkawinan campuran, maka oleh mereka yang menurut hukum yang berlaku bagi pihak masing-masing berwenang mencatat perkawinan, diberikan surat keterangan bahwa syarat-syarat telah dipenuhi.

(3) Jika pejabat yang bersangkutan menolak untuk memberikan surat keterangan itu, maka atas permintaan yang berkepentingan, Pengadilan memberikan keputusan dengan tidak beracara serta tidak boleh dimintakan banding lagi tentang soal apakah penolakan pemberian surat keterangan itu beralasan atau tidak.

(4) Jika Pengadilan memutuskan bahwa penolakan tidak beralasan, maka keputusan itu menjadi pengganti keterangan yang tersebut ayat (3).

(5) Surat keterangan atau keputusan pengganti keterangan tidak mempunyai kekuatan lagi jika perkawinan itu tidak dilangsungkan dalam masa 6 (enam) bulan sesudah keterangan itu diberikan.

\section{Pasal 61}

(1) Perkawinan campuran dicatat oleh pegawai pencatat yang berwenang.

(2) Barang siapa melangsungkan perkawinan campuran tanpa memperlihatkan lebih dahulu kepada pegawai pencatat yang berwenang surat keterangan atau keputusan pengganti keterangan yang disebut dalam Pasal 60 ayat (4) Undang-undang ini dihukum dengan hukuman kurungan selama-lamanya 1 (satu) bulan.

(3) Pegawai pencatat perkawinan yang mencatat perkawinan sedangkan ia mengetahui bahwa keterangan atau keputusan pengganti keterangan tidak ada, dihukum dengan hukuman kurungan selama-lamanya 3 (tiga) bulan dan dihukum jabatan.

\section{Pasal 62}

Dalam perkawinan campuran kedudukan anak diatur sesuai dengan Pasal 59 ayat (1) Undang-undang ini.

Menurut pasal-pasal pada undang-undang perkawinan tersebut, dapat kita lihat adanya pengertian perkawinan campuran sebagaimana tertulis dalam Pasal 57. Penafsiran atas pasal tersebut bermakna bahwa perkawinan campuran yang dimaksud ialah apabila salah satu pihak berkewarganegaraan asing (WNA) 
dan pihak lain yang berkewarganegaraan Indonesia (WNI). Selanjutnya ketentuan pada Pasal 58 menjelaskan bahwa perkawinan campuran yang dilakukan oleh seorang WNI dan seorang WNA dapat memilih untuk memperoleh status kewarganegaraan dari salah satu negara, yaitu kewarganegaraan dari suami maupun isterinya. Perpindahan kewarganegaraan tersebut baik persyaratan maupun ketentuannya berdasarkan cara-cara yang telah ditentukan dalam Undang-Undang Kewarganegaraan Republik Indonesia yang berlaku, yaitu Undang-Undang Nomor 12 Tahun 2006 Tentang Kewarganegaraan Republik Indonesia yang merupakan perubahan atas Undang-Undang Nomor 62 Tahun 1958. Jika status kewarganegaraan tersebut sudah diberikan oleh negara (misalnya WNA memilih untuk merubah kewarganegaraannya menjadi warga negara Indonesia karena menikah dengan seorang WNI), maka status kewarganegaraan tersebut menentukan hukum yang berlaku baginya, baik mengenai hukum publik maupun mengenai hukum perdata. Artinya hukum yang dianut dan harus ia patuhi adalah hukum negara dimana ia menjadi warga negara tersebut (Pasal 59 ayat 1).

Undang-Undang tentang Kewarganegaraan Republik Indonesia tidak serta merta memberikan status kewarganegaraan Indonesia bagi seorang wanita WNA yang menikah dengan seorang pria WNI. Namun jika wanita WNA tersebut ingin menjadi WNI maka ia harus mengajukan permohonan secara resmi sesuai peraturan yang berlaku. Demikian juga seorang wanita WNI yang menikah dengan seorang pria WNA dapat tetap mempertahankan kewarganegaraan Indonesia, bila ia hendak mengikuti kewarganegaraan suaminya menjadi WNA, maka wanita tersebut diharuskan untuk mengajukan permohonan sesuai peraturan yang berlaku seperti tertuang dalam Pasal 7 dan 8 Undang-Undang Kewarganegaraan Lama (Undang-Undang Nomor 62 Tahun 1958), dan Pasal 26 Undang-Undang Kewarganegaraan Baru (UndangUndang Nomor 12 Tahun 2006). Hal yang demikian itu dapat menimbulkan perbedaan kewarganegaraan dalam keluarga suatu perkawinan campuran. ${ }^{37}$

Adapun mengenai tempat dan tata cara pencatatan perkawinan campuran tidak ada diatur secara khusus dalam Undang-Undang Nomor 1 Tahun 1974, namun jika kita mengacu pada Pasal 59 ayat (2) undang-undang ini, maka akan tergambar bahwa bentuk suatu perbuatan hukum dilakukan menurut hukum dimana perbuatan hukum itu terjadi. Oleh karena itu tata cara

\footnotetext{
${ }^{37}$ Leonora Bakarbessy and Sri Handajani, "Kewarganegaraan Ganda Anak Dalam Perkawinan Campuran dan Implikasinya Dalam Hukum Perdata Internasional," Jurnal Perpsektif XVII No.1 (2012).
} 
dan pencatatan perkawinan campuran hemat penulis dilakukan menurut hukum nasional Indonesia. Sesuai dengan bunyi pasal tersebut, maka tempat pencatatan perkawinan campuran antara warga negara Indonesia dan warga negara asing dilakukan/dicatatkan oleh pegawai pencatatan perkawinan pada kantor catatan sipil dalam wilayah dimana perkawinan itu dilangsungkan.

Selanjutnya dalam Pasal 60, undang-undang perkawinan menjelaskan dalam beberapa ayat tentang ketentuan dan syarat-syarat untuk melaksanakan perkawinan campuran, yang harus dipenuhi oleh masing-masing pihak sesuai hukum yang berlaku bagi masing-masing pihak tersebut. Misalnya adanya surat keterangan tentang berbagai persyaratan perkawinan yang dikeluarkan oleh pihak-pihak (pejabat) dari instansi yang berwenang menurut hukum yang berlaku bagi masing-masing pihak yang akan melangsungkan perkawinan campuran. Apabila terjadi penolakan dari pejabat atau instansi yang berwenang untuk mengeluarkan surat keterangan sebagai persyaratan perkawinan campuran, maka pihak yang berkepentingan dapat meminta keputusan (penetapan) dari Pengadilan untuk memberikan pertimbangan hukum apakah penolakan tersebut beralasan hukum atau tidak.

Kemudian selanjutnya Pasal 61 ayat (1) menegaskan kembali bahwa perkawinan campuran dicatatkan oleh pegawai pencatat perkawinan yang berwenang. Dalam hal ini tentunya bagi yang beragama Islam dicatatkan pada Kantor Urusan Agama, sedangkan yang beragama selain Islam pencatatannya pada Kantor Kependudukan dan Pencatatan Sipil setempat. Sementara pada ayat (2) dan (3) mengatur tentang ketentuan sanksi pidana bagi pelaku maupun pihak pegawai pencatat perkawinan yang dengan sengaja melanggar atau memanipulasi ketentuan dan syarat-syarat untuk melaksanakan perkawinan campuran yang seharusnya dipenuhi oleh kedua calon mempelai.

Demikianlah ketentuan-ketentuan yang diatur dalam Undang-Undang Nomor 1 Tahun 1974 Tentang Perkawinan yang mengatur tentang perkawinan campuran. Pada pokoknya perkawinan campuran yang dilangsungkan oleh seorang warga negara Indonesia dan seorang warga negara asing tidak dilarang oleh hukum yang berlaku bahkan dapat memperoleh legalitaas atau pengakuan dari negara, selama segala syarat dan ketentuan yang diatur oleh hukum masing-masing negara asal kedua mempelai tersebut terpenuhi serta tidak ada larangan bagi keduanya untuk melangsungkan pernikahan.

\section{Simpulan}


yaitu :

Berdasarkan apa telah dibahas, beberapa point yang bisa disimpulkan

1. Ada dua Kategori Praktek perkawinan campuran di Indonesia yaitu perkawinan campuran lintas agama/ beda agama dan perkawinan campuran lintas negara/ perbedaan kewarganegaraan.

2. Perkawinan campuran yang dilaksanakan di Indonesia mengacu pada hukum perkawinan yang berlaku di Indonesia. Untuk melaksanakan perkawinan campuran antara warga negara Indonesia dengan warga negara lain, secara umum harus dipenuhi terlebih dahulu persyaratan-persyaratan perkawinan sebagaimana diatur dalam undang-undang perkawinan.

3. Perkawinan campuran lintas Negara yaitu perkawinan yang dilakukan oleh Warga Negara Indonesia dengan Warga Negara Asing dibolehkan dan mendapat legalitas / pengakuan Negara, selama segala syarat dan ketentuan yang diatur oleh hukum masing-masing negara asal kedua mempelai tersebut terpenuhi serta tidak ada larangan bagi keduanya untuk melangsungkan pernikahan.

4. Hukum Islam dan Hukum Positif Indonesia membolehkan perkawinan antara dua orang yang berlainan kewarganegaraan, namun mengharamkan perkawinan campuran karena perbedaan agama dan tidak mendapatkan legalitas hukum

\section{Daftar Pustaka}

Abdul Aziz, Masyhuri. Masalab Keagamaan: Hasil Muktamar dan Munas Ulama Nabdhatul Ulama Surabaya. Surabaya: PP Rabithah Ma'ahidil Islamiyah dan Dinamika Press., 1977.

Abdullah, H.Ainuddin. Beberapa Materi Kultum : Upaya Meningkatkan Wawasan keIslaman, Gairah Beribadah dan Kualitas Ibadah. Banjarmasin: PT. Grafika Wangi, 2020.

Abi Bakr al-Suyuthi, Abdurrahman bin. Al-Durr al-Mantsur, (al-Maktabah alSyamilah) Jilid II. Jilid II. Al-Maktabah al-Syamilah, n.d.

Adlani, dkk., H.A Nazri. Himpunan Fatwa Majelis Ulama Indonesia. Jakarta: Majelis Ulama Indonesia, 1997.

Ali as-Syairazi, Ibrahim bin. Al-Muhadzzab Fi Figh al-Imam al-Syafi i. Jilid III. Beirut: Dar al-Kutub al-'Tlmiyyah, tt, n.d.

Ali, Umar bin. Al-Lubaab Fi Uluum al-Kitab. Jilid IV. Beirut: Dar al-Kutub al'Ilmiyyah, 1998. 
Al-Jaziri, Abdurrahman. Kitab Al-Fiqh 'Ala al-Madzabib al-Arba'Ah. Beirut: Dar al-Kutub al-'Ilmiyyah, tt, n.d.

Al-Sariy, Ibrahim bin. Ma'aniy al-Qur'an Wa I'robubu Lil Zajjaaj. Jilid I. Beirut: 'Alam al-Kutub, 1988.

Alyasa, Abu Bakar. Perkawinan Muslim dengan Non-Muslim. Nangroe Aceh Darussalam: Dinas Syari'at Islam, 2008.

At-Thohir, Muhammad. Tafsir Al-Tahriir Wal Tanwiir. Jilid II. Tunisia: al-Daar al-Tunisiyyah, 1984.

At-Thorify, Abdul Aziz. Al-Tafsir wal Bayan li Abkaam al-Qur'an. Jilid I. Riyadh: Maktabah Dar al-Minhaj, 2017.

Azizy, A.Qodry. Eklektisisme Hukum Nasional Kompetisi antara Hukum Islam dan Hukum Umum. Yogyakarta: Gama Media, 2004.

Az-Zuhaily, Wahbah. Wabbah Az-Zubailiy, al-Fiqh al-Islamiy $W a$ Adillatuh, Jakarta: Gema Insani, 2011) Jilid IX. Jilid IX. Jakarta: Gema Insani, 2011.

Bakarbessy, Leonora, and Sri Handajani. "Kewarganegaraan Ganda Anak Dalam Perkawinan Campuran dan Implikasinya Dalam Hukum Perdata Internasional." Jurnal Perpsektif XVII No.1 (2012).

Hasan Khan, Shiddiq. Fath Al-Bayan Fi Maqashid al-Qur'an,. Jilid II. Beirut: Dar al-Kutub al-'Ilmiyyah, tt, n.d.

Karsayuda, M. Perkawinan Beda Agama: Menakar Nilai-nilai Keadilan Kompilasi Hukum Islam. Yogyakarta: Total Media, 2006.

Mubarak, Jaih. Pembaruan Hukum Perkawinan di Indonesia. Bandung: Simbiosa Rakatama Media, 2015.

Muhammad al-Mawardi, Ali bin. Al-Hawi al-Kabir. Jilid IX. Beirut: Dar alKutub al-'Ilmiyyah, 1994.

Muhammadiyah, PP. Tanfidz. Keputusan Muktamar Tarjih Mubammadiyah XII, Malang. Yogyakarta: PP Muhammadiyah, 1990.

Rasyid Ridha, Muhammad. Tafsir Al-Manar. Jilid III. Beirut: Dar al-Fikr,tt, n.d.

Republik Indonesia, Departemen Agama. Kompilasi Hukum Islam. Instruksi Presiden Nomor 1, 1991.

Rosana, Ellya. "Hukum dan Perkembangan Masyarakat." Jurnal TAPLs 9 No.1 (June 2013).

Sabiq, Sayyid. Fiqh Al-Sunnah. Jilid II. Beirut: Dar al-Kitab al-Arabi, 1985.

Undang-Undang Nomor 1 Tabun 1974 Tentang Perkawinan Sebagaimana Telab Diubah Dengan Undang-Undang Nomor 16 Tahun 2019. Surabaya: Arkola, 2000. 
